\title{
TECHNICAL ASSESSMENT OF OLD BUILDINGS BY FUZZY APPROACH
}

\section{J. KONIOR ${ }^{1}$}

A group of old apartment houses with the age over 100 years (that is those carried out before the First World War) takes an important place in polish building resources. Technical maintenance of apartment houses, traditional methods erected, is nowadays and will be a valid problem in the nearest future. The results of the work refer to the general population, estimated for 600 objects, that is about $20 \%$ of municipal downtown apartment houses in Wrocław.

The purpose of the research was to identify an influence of widely considered maintenance of apartment houses on a degree and intensity of their elements' deterioration. The goal of the work has been fulfilled by symptoms' analysis of declining of inspected elements' exploitation values, that is identification of mechanics of their defects arising.

The range of the work has required creation of original qualitative model of pinpointed defects and its transfer into quantitative one. It has made possible to analyse the reason - effect phenomena ,defect - technical wear" relevant to the most important elements of Wrocław downtown district's apartment houses. The research procedure has been conducted in accordance of fuzzy sets theory which made possible to describe qualitative model of pinpointed defects and its transfer into a quantitative one.

Keywords: buildings, technical wear, defects, fuzzy sets

\section{INTRODUCTION}

A group of old apartment houses (that is those erected before the First World War) takes an important place in polish building resources. This group includes about $10.1 \%$ of the whole number of urban flats [7]. What is more, the importance of this type of building relies on the fact that it

${ }^{1}$ PhD., Eng., Wroclaw University of Science and Technology, Faculty of Civil Engineering, Department of Construction Technology and Management, Wybrzeże Wyspiańskiego 27, 50-370 Wrocław, Poland, e-mail: jaroslaw.konior@pwr.edu.pl 
takes part in creating of an urban environment. A full value of the urban environment means an effort of many generations. The effort is efficient if continuity of the following processes is kept: erection - maintenance - repair - maintenance - modernisation - maintenance, ..., until demolition of a building. Due to political and economic conditions of the twentieth century the existing rule has been upset in Europe. A land development of many cities has been destroyed as a result of the war actions. After the Second World War, in plenty of countries in Central Europe, additional devastation factors have appeared as a consequence of lack of houses, people's migration and a deficiency of technical care as well, a majority of them as a result of deprivation of a law of property belonged to proprietors of houses. At present, an action needs to be directed on repair of the old land development. Doubtless, cultural aspects motivate all this action. As to estimate its technical and economic justification a degree of a technical wear of the old land development must be recognised and calculated.

The paper is a result of a technical research and analyses as for the old apartment houses in Wrocław, Poland [7]. The aim of the analysis means providing information which should help to direct an action, connected with this group of the apartment houses. A method of scientific research on calculating a technical wear of an apartment house and the detailed results of the technical wear of 23 considered apartment houses' elements have been presented in the paper as well.

\section{METHODICAL ASSUMPTIONS}

The degree of a technical wear of a building object (or its elements) can be defined according to the simplified mathematical formulas. There are a few well known formulas thoroughly described by Ross [13], Unger [13], Romsterfen [13] and Eytelwein [13]. The methodology has also been presented and recommended for old buildings technical assessment even before a Second World War by Trojanowski [13]. The authors treat the degree of a technical wear $\mathrm{z}$ of apartment houses (or their elements) as a function of their expected life $\mathrm{T}$ and a period of their hitherto use $\mathrm{t}$. A form of the function is dependent on conditions of building maintenance WU.

A direct application of such simple formulas would result in drawing misleading conclusions - from methodical point of view - as to the technical wear of the old land development. It is very difficult to attribute to the considering apartment houses only one means of maintenance described by the formulas. As a result of this incompatibility, a decision has been made to compare the technical wear calculated by the theoretical formulas to the observed degree of a technical wear of the apartment houses and their structural elements. The real degree of a technical wear has been 
qualified on the ground of non-destructive testing of the building elements. The technical wear of 23 structural elements chosen from the technologically and constructional homogeneous group of the 102 (out of 160) apartment houses has been established [7].

The results of research considering the apartment houses and their elements have been worked out as to make them comparable to the results calculated according to the formulas. Such leading to comparison means classifying the testing objects according to the classes, which determine the degree of the technical wear classified by Trojanowski [13]. The technical wear $0 \%-15 \%$ has been classified to the class I, $16 \%-30 \%$ to the class II, $31 \%-50 \%$ to the class III, $51 \%-70 \%$ to the class IV, $71 \%-100 \%$ to the class V. Owing to the fact that all considering apartment houses belong to the same group of their age it is possible to assume that the class of the technical wear corresponds to the conditions of building maintenance. Therefore, the equivalence has been defined: a poor maintenance - the class IV, V, an average maintenance - the class III, an above than an average maintenance - the class II, a very well cared maintenance - the class I. The procedure enabled to compare the technical wears calculated according to the theoretical formulas to the observed ones, based on technical inspections and testing methods.

\section{RESEARCH SAMPLE AND PROBLEM IDENTIFICATION}

The analysis has been applied to the downtown apartment houses erected before the First World War in the city centre of Wrocław [7]. They are the apartment houses, which have been built up in nineteenth and twentieth century. The buildings are situated in the part of the city, which (as a district from very few ones) had not been completely destroyed by the war activities. The apartment houses are three - or four - storey buildings, made of bricks, erected in longitudinal, usually three row structural systems. Apart from the floors over the basement, which are solid ones, all the interstorey floors represent typical wooden floors. All the buildings are covered with wooden rafter framing, usually purlin - collar one. The staircases compose of wooden or steel structural elements with wooden flights of steps.

The comparison of the building elements technical wear calculated according to the theoretical formulas $\mathrm{Zt}$ and defined after observation with testing $\mathrm{Ze}$. There is an easily noticeable difference between the theoretical technical wear and the real one for the relevant age of the building elements. The research samples are related to the II, III and IV class of the main walls technical wear. Durability T, which stands for "expected life", has been applied as a'posteriori data and replaced 
literature values of estimated one. Thus, durability $\mathrm{T}$ meant the maximum age of a building element - 150 or 174 years for different classes and periods of elements life. The results, considering the group of 102 apartment houses, refer to above than an average (16 measurements), an average (61) and poor (25) maintenance. The tested main walls were neither very well (the class I) nor very poorly (the class V) cared. They have been used for $71-130$ years and the age of three of them is 170,172 and 174 years.

The values of the observed technical wear have been put in ascending order of the building elements age (it happens that the different values of the technical wear Ze correspond with the same age of the building elements and on the other way round). Such prepared values of the function and its arguments $(\mathrm{Ze}=\mathrm{f}\{\mathrm{t}\})$ have been extended by calculated values of the theoretical technical wear which enabled to define the difference $\mathrm{Ze}-\mathrm{Zt}$ as a function of building elements age.

\section{COMPARATIVE ANALYSIS OF TECHNICAL WEAR}

On the ground of the analysis a repeated regularity has been noticed - the observed technical wear is greater than the theoretical one during the first stage of building elements use: $\mathrm{Ze}=\mathrm{f}(\mathrm{t})>\mathrm{Zt}=\mathrm{f}(\mathrm{t})$. After exceeding some, possible to determine, age $t_{i}$ the mentioned relation is inversely proportional and works until the maximum value of building elements age: $t_{\max }=174$ years. In the considering example of the main walls the age, from which the theoretical technical wear becomes higher than the observed one, is 87 years (the class III). The difference is broadening with the rise of the building elements age what indicates imperfection in calculating the technical wear according to the technical formulas. The mean deviation of the theoretical and the observed technical wear AVR (III) is -3.13. It must be a rule because all observed elements of the apartment houses show signs of "under-expected life" during the first stage of building elements use and "over-expected life" after exceeding the age $t_{i}$. There is the only period, approximately defined as $\left(t_{i}-T / 10\right)<t_{i}<\left(t_{i}+T / 10\right)$, where the theoretical and the observed technical wear vary not more than $10 \%$.

The main conclusion from the preliminary research is that both technical wears - the observed and the theoretical ones vary from each other a lot. Main drawback of theoretical formulas is the fact that they rely on only two factors (the age of building element $t$ and its durability $\mathrm{T}$ ) and do not represent any conditions of their maintenance. The main disadvantage of defining building elements deterioration is difficulty and subjectivity of assessment during technical inspections of buildings. Nevertheless, the estimated observed technical wear better or worse reflects the state of reality. 
The deterioration of building elements, on the whole, should be the result of two major factors: their age and the conditions of their maintenance. Which one of both has a grater influence on old apartment houses elements' technical wear? It does not seem to be an age because for the same age of the building element its technical wear can be as 20 as $100 \%$ and the other way round. What is more, the observed technical wear of the considered apartment houses does not increase with the growth of their age while theoretical curves do.

\section{FUZZY SETS THEORY RESEARCH APPROACH}

A pre-stage of the essential research has aimed to undergo a qualitative analysis of detected defects and identify all particular defects of the considered apartment houses' elements. A crucial point for the whole work led to defining the pinpointed defects (according the same source of their arising and similarity of effects, which they caused) and categorising them into four groups [8]:

I. Mechanical defects of structure and surface of elements (UM);

II. Defects of elements caused by water penetration and humidity migration (UW);

III. Defects symptomatic of loss of wooden elements original shape (UD);

IV. Defects of wooden elements attacked by insects - technical pest of wood (UP).

Advantages of fuzzy theory made possible to describe the defects, representing three middle states (II, III, IV) of conditions of the building elements' maintenance, in a clear quantitative (measurable) aspect. Doubtless, fuzzy conditions are fully represented in these mid-states.

In such a case, a total defect of the building element is union of sets treated as a sum of group of defects (1). Each group of defects is the set composed of the elementary defects. There is an intermediate stage between detecting defects at an elementary level, existing in everyday building's practice, and integration them into groups formed accordingly to the similarity of running technical wear process. It relays on categorising defects of the same type but different intensity (e.g. loosening of plaster and its falling off). Each of the formed in such a way groups of the defects shows the phenomena of intersection of two or three elementary fuzzy sets (2). It has been written as a membership function presented and described for practical application by Kacprzyk [6].

Group of defects:

- $\mathrm{UM}=\left\{\mathrm{u}_{1}, \mathrm{u}_{2}, \ldots, \mathrm{u}_{14}\right\}$ - mechanical defects;

- $\mathrm{UW}=\left\{\mathrm{u}_{15}, \mathrm{u}_{16}, \ldots, \mathrm{u}_{23}\right\}$ - water penetration and humidity migration defects;

- $\mathrm{UD}=\left\{\mathrm{u}_{24}, \mathrm{u}_{25}, \ldots, \mathrm{u}_{28}\right\}$ - wooden elements original shape defects; 
- $\mathrm{UP}=\left\{\mathrm{u}_{29}, \mathrm{u}_{30}\right\}$ - defects of wooden elements attacked by insects.

Union of fuzzy sets - group of defects:

$$
\mathrm{U}(\mathrm{II}, \mathrm{III}, \mathrm{IV})=\mathrm{UM}(\mathrm{II}, \mathrm{III}, \mathrm{IV}) \cup \mathrm{UW}(\mathrm{II}, \mathrm{III}, \mathrm{IV}) \cup \mathrm{UD}(\mathrm{II}, \mathrm{III}, \mathrm{IV}) \cup \mathrm{UP}(\mathrm{II}, \mathrm{III}, \mathrm{IV})
$$

Defects of the same type, but different intensity, e.g.:

- $\left\{\mathrm{u}_{13}, \mathrm{u}_{14}\right\}=\mathrm{U} 7 \Leftrightarrow$ loosening of plaster and its falling off.

Intersection of two or three elementary fuzzy sets as a membership function:

(2) $\mu_{\mathrm{U}}=\left(\mu_{\mathrm{u} 1} \wedge \mu_{\mathrm{u} 2}\right) \vee\left(\mu_{\mathrm{u} 3} \wedge \mu_{\mathrm{u} 4}\right) \vee\left(\mu_{\mathrm{u} 5} \wedge \mu_{\mathrm{u} 6}\right) \vee\left(\mu_{\mathrm{u} 7} \wedge \mu_{\mathrm{u} 8}\right) \vee\left(\mu_{\mathrm{u} 9} \wedge \mu_{\mathrm{u} 10}\right) \vee\left(\mu_{\mathrm{u} 11} \wedge \mu_{\mathrm{u} 12}\right) \vee$

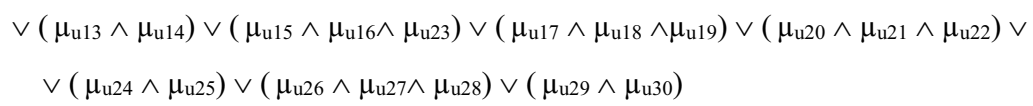

The essential probabilistic measurement in conventional sets analysis was the probability of appearing the elementary defect $\mathrm{p}\left(\mathrm{u}_{\mathrm{j}}\right)$. Although it would not be a mistake a simple transfer of the probability $\mathrm{p}\left(\mathrm{u}_{\mathrm{j}}\right)$ into the degree of membership $\mu_{\mathrm{uj}}$, linearly described by the membership function $\mathrm{f}\left(\mu_{\mathrm{uj}}\right)$, by applying Zadeh [15] function (8) to increasing an intensity of a fuzzy set's contrast fuzzy theory features have been explicated in recently published papers $[1,2,3,4,5,8,9,10,11]$. The intensity of the contrast ascends the membership degrees, which are equal or higher than 0,5 and descends those of them which are lower than 0,5 .

Zadeh function applied to increase an intensity of a fuzzy set's contrast $\mathrm{A} \subseteq \mathrm{X}$ :

$$
f\left(\mu_{u j}\right) \Leftrightarrow \mu_{\text {INT(A) }}(x)=\left\{\begin{array}{c}
2\left(\mu_{A}(x)\right)^{2}, \forall x: \mu_{A}(x)<0,5 \\
1-2\left(1-\mu_{A}(x)\right)^{2}, \forall x: \mu_{A}(x) \geq 0,5
\end{array}\right.
$$

where:

$\mu_{\mathrm{A}} \Leftrightarrow \mathrm{p}\left(\mathrm{u}_{\mathrm{j}}\right)-$ degree of defects membership $\mu_{\mathrm{uj}}$ to elementary fuzzy sets $\mathrm{u}_{1} \div \mathrm{u}_{30} \Leftrightarrow$ frequency of occurring defects;

$\mathrm{f}\left(\mu_{\mathrm{uj}}\right)$ - membership function at range $[0,1]$.

The last stage of the created model was an estimation of quantity of the elementary defects' influence $u_{j}$ on the total defect. The original function (3) has been applied for models of frequency of the defects occurring, expressed by the membership function (5) with the power of the defects (represented by the correlation coefficient).

Total degree of building element defect $\mathrm{S}(\mathrm{U}) \Leftrightarrow \mu_{\mathrm{U}}$ at range $[0,1]$ :

$$
\mu_{\mathrm{uj}}=\left[\mathrm{f}\left(\mu_{\mathrm{uj}}\right)\right]^{1 / \mathrm{r}(\mathrm{Z})}
$$

The result of the proposed formula is a following change of the membership function $f\left(\mu_{\mathrm{uj}}\right) \in[0,1]$ :

$$
\mathrm{r}(\mathrm{Z}) \rightarrow 0 \Rightarrow \mu_{\mathrm{uj}} \rightarrow 0 \quad \text { and } \quad \mathrm{r}(\mathrm{Z}) \rightarrow 1 \Rightarrow \mu_{\mathrm{uj}} \rightarrow \mathrm{f}\left(\mu_{\mathrm{uj}}\right)
$$




\section{CAUSE - EFFECT FUZZY MODEL}

An application of the function in fuzzy sets categories enabled to transfer the immeasurable variables into the measurable ones. The proposed model answers, in the quantitative way, the question how deeply the building element is defected - see Plebankiewicz [10, 11]. It is easily noticeable that the fuzzy sets research, more frequently than the probabilistic analysis, indicates those of defects belonged to the group I, which are symptoms of the building element overall deterioration.

Thus, a decision was made to make an attempt on a practical solution (while still treating sets $U$ and $\mathrm{Z}$ as fuzzy ones), that involved application of the so called fuzzy relation equations that are particularly useful in diagnostics of conditional phenomena, i.e. cause - effect relations, table 1.

Table 1. Result of fuzzy sets research of reason - effect relations "defect - technical wear" for 10 chosen apartment houses elements

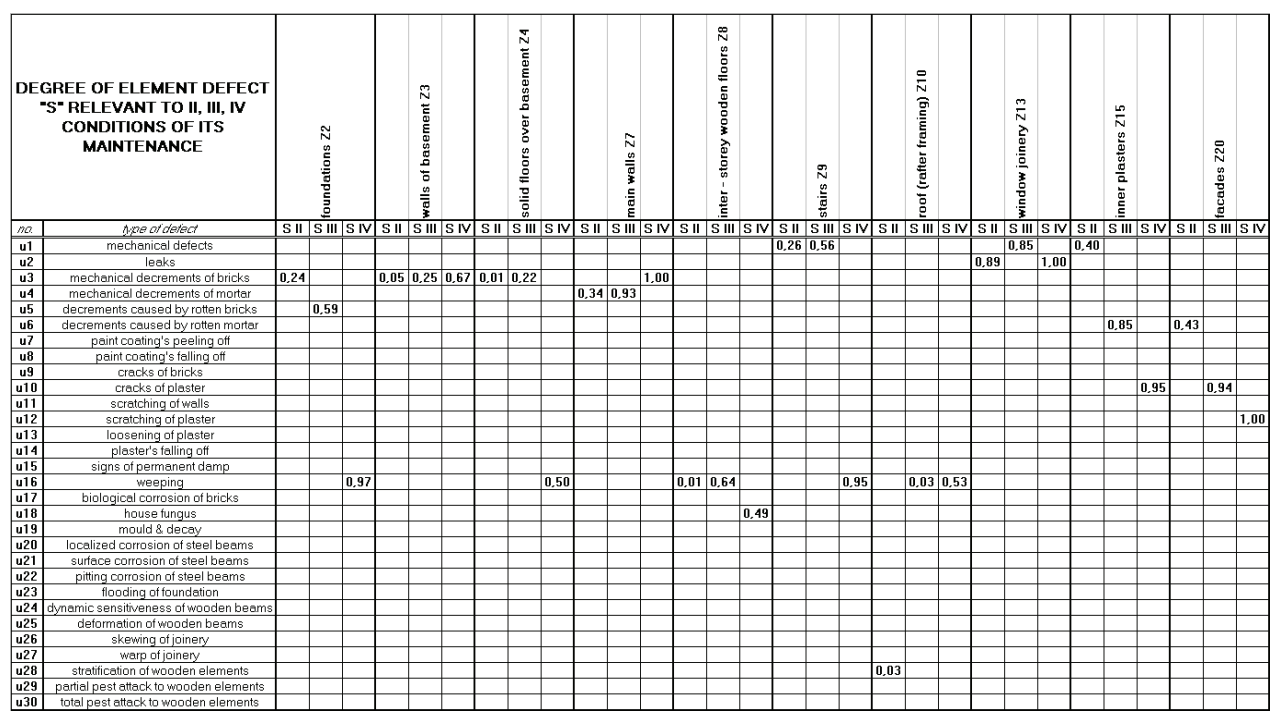

\section{FUZZY RELATIONS}

Conventional (non-fuzzy) sets enabled adequate expression of certain precisely defined properties of theoretical and observed conditions. The relation (non-fuzzy) enabled adequate expression of precisely defined interdependence between variables of these conditions (if such dependences 
existed). Mathematical operations on applied fuzzy relations have been firstly laid out by Sanchez [12].

The problem appeared when it was necessary to express interdependences that were defined not very precisely, e.g.: What is the impact (cause) of defects on 10 selected for research buildings elements technical wear degrees? The notion of a fuzzy relation was used to define the problem and record parameters of the phenomenon. Each pair of arguments $(\mathrm{x}, \mathrm{y}) \Leftrightarrow(\mathrm{z}, \mathrm{u})$ was assigned with a degree (measure) of affiliation that expresses intensity of occurrence of relations between $\mathrm{Z}$ and $\mathrm{U}$, that is how $\mathrm{Z}$ depends on $\mathrm{U}$, i.e. what interdependences (correlations) occur between them. It was assumed that $Z$ and $U$ as non-sharp sets, determined under conditions of fuzziness, may be in a certain relation with one another. As a result, the fuzzy relation was defined as follows [6, 12]:

A two-argument fuzzy relation $R$ between two sets $Z=\{z\}$ and $U=\{u\}$ is a relation defined as a fuzzy set determined on the Cartesian product $\mathrm{Z} \times \mathrm{U}$ :

$$
\mathrm{R} \subseteq \mathrm{Z} \times \mathrm{U}=\{(\mathrm{z}, \mathrm{u}): \mathrm{z} \in \mathrm{Z}, \mathrm{u} \in \mathrm{U}\}
$$

it is thus a set of pairs:

$$
\mathrm{R}=\left\{\left(\mu_{\mathrm{R}}(\mathrm{z}, \mathrm{u}),(\mathrm{z}, \mathrm{u})\right)\right\}, \forall \mathrm{z} \in \mathrm{Z}, \forall \mathrm{u} \in \mathrm{U}
$$

where $\mu_{\mathrm{R}}: \mathrm{Z} \times \mathrm{U} \rightarrow[0,1]$ is an affiliation function of the fuzzy relation $\mathrm{R}$ attributing each pair $(\mathrm{z}, \mathrm{u})$ : $\mathrm{z} \in \mathrm{Z} \mathrm{u} \in \mathrm{U}$, with its affiliation degree $\mu_{\mathrm{R}}(\mathrm{z}, \mathrm{u}) \in[0,1]$, being a measure of intensity of the fuzzy relation $\mathrm{R}$ between $\mathrm{Z}$ and $\mathrm{U}$.

The fuzzy relation may therefore be presented as follows:

$$
\mathrm{R}=\sum_{\mathrm{z}, \mathrm{u}} \mu \mathrm{R}(\mathrm{z}, \mathrm{u}) /(\mathrm{z}, \mathrm{u})
$$

The main fuzzy relation (8), defined at a general level in this paper, is the relation pertaining to generating faults $\mathrm{Z}$ and the occurrence of unforeseen works $\mathrm{U}$ during the construction execution. $\mathrm{A}$ measure of relation between $Z$ and $U$ are values equivalent to the affiliation degree $\mu_{R} \Leftrightarrow \mu_{Z, u}$. The fuzzy relation $\mathrm{R}=\mathrm{Z} \times \mathrm{U}$ defined in this manner was presented as a fuzzy relation matrix.

The matrix components, representing fuzzy relations between $\mathrm{Z}$ and $\mathrm{U}$ inform us about the degree to which the fuzzy event of making design, contractor's and other faults (expressed by the intensity of occurrence of these faults) has an impact on the scale (degree) of the supplementary and variation works in relation to the basic (foreseen) works.

For all fuzzy relations $\mathrm{R} \subseteq \mathrm{Z} \times \mathrm{U}$ the following parameters were determined in fuzzy relation matrix $\mathrm{R}=\mathrm{Z} \times \mathrm{U}$ :

- domain of a fuzzy function $\mathrm{R} \subseteq \mathrm{Z} \times \mathrm{U}$, referred to as the first projection of the fuzzy function and marked as 'dom R': 
(9)

$$
\mu_{\mathrm{domR}}(\mathrm{z})=\bigvee_{\mathrm{z} \in \mathrm{Z}} \mu_{\mathrm{R}}(\mathrm{z}, \mathrm{u}) \Leftrightarrow \bigvee_{\mathrm{i}=1}^{\mathrm{n}} \mathrm{z}_{\mathrm{i}}=\max \left\{\mathrm{z}_{1}, \mathrm{z}_{2}, \ldots, \mathrm{z}_{\mathrm{n}}\right\}
$$

- range of fuzzy relation $\mathrm{R} \subseteq \mathrm{Z} \times \mathrm{U}$, referred to as the second projection of the fuzzy relation and marked as 'ran R':

$$
\mu_{\operatorname{ranR}}(\mathrm{u})=\bigvee_{\mathrm{u} \in \mathrm{U}} \mu_{\mathrm{R}}(\mathrm{z}, \mathrm{u}) \Leftrightarrow \bigvee_{\mathrm{j}=1}^{\mathrm{m}} \mathrm{u}_{\mathrm{j}}=\max \left\{\mathrm{u}_{1}, \mathrm{u}_{2}, \ldots, \mathrm{u}_{\mathrm{m}}\right\}
$$

- height of fuzzy relation $\mathrm{R} \subseteq \mathrm{Z} \times \mathrm{U}$, referred to as the global projection of the fuzzy relation and marked as $\mathrm{h}(\mathrm{R})$

$$
\mathrm{h}(\mathrm{R})=\mathrm{V}_{\mathrm{z} \in \mathrm{Z}} \mu_{\operatorname{domR}}(\mathrm{z})=\underset{\mathrm{u} \in \mathrm{U}}{\mathrm{V}} \mu_{\mathrm{ranR}}(\mathrm{u})=\mathrm{Z}_{\mathrm{z} \in \mathrm{Z}} \mathrm{U}_{\mathrm{u} \in \mathrm{U}} \mu_{\mathrm{R}}(\mathrm{z}, \mathrm{u})
$$

and, when $h(R)=1$ then the fuzzy relation is normal and, if $h(R)<1$ it is subnormal.

All fuzzy relations $R \subseteq Z \times U$ (8) corresponding to 30 mostly appeared pinpointed defects $U_{i j}$ in 4 groups of 10 selected for research technical wear degrees $Z_{j}$ have been determined in fuzzy relation matrix $\mathrm{R}=\mathrm{Z} \times \mathrm{U}$ presented in the table 2 .

Table 2. Matrix of fuzzy relation $\mathrm{R}=\mathrm{Z}$ x U for 10 most critical building's elements and 30 detected defects

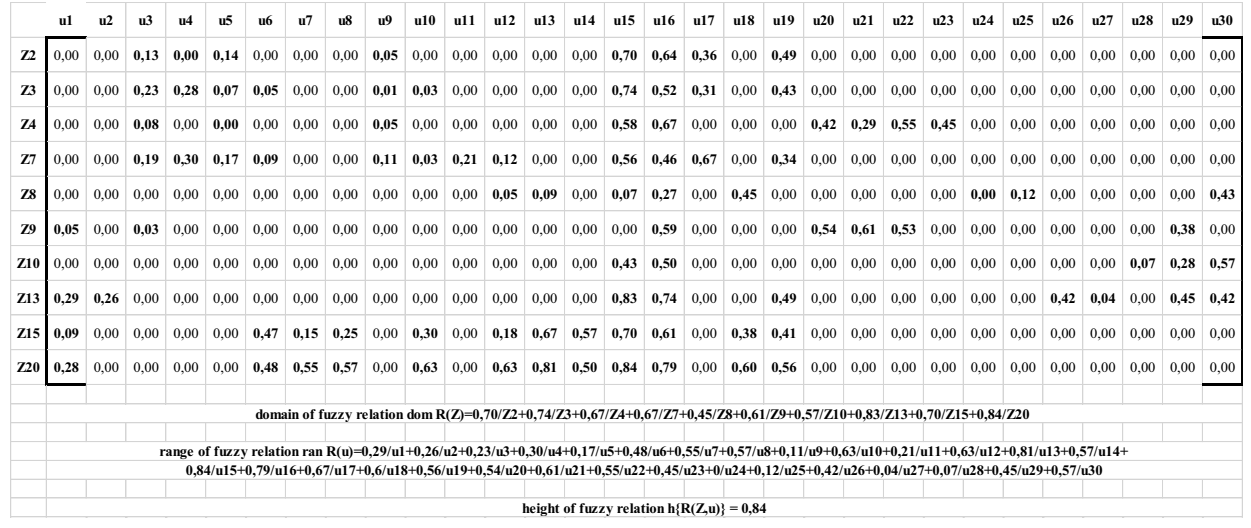

It was possible to calculate the range, the domain (9) and the height (10) of the fuzzy relations $\mathrm{R} \subseteq \mathrm{Z} \times \mathrm{U}$ as quantitative values. There are three main conclusions from elaborating the relations $\mathrm{R} \subseteq \mathrm{Z} \times \mathrm{U}$ in fuzzy sets categories:

- exactly $30 \%$ out of $300 \mathrm{Uij}$ and $\mathrm{Zj}$ relations pair are linked with each other in "i" columns, $1 / 3$ of them with $R$ over 0.5 which indicates significant alliances

- the height (11) $h(R)$ of the tested fuzzy relations $R \subseteq Z \times U$ is getting to normal $h(R)=1$ not only as one maximum in the relation matrix but appears in 9 cases $\left(3 \%\right.$ of $U_{i j}$ and $Z_{j}$ relations) 


\section{CONCLUSIONS}

The goal of the work - transfer the weight of apartment houses' technical assessment from the qualitative form into the quantitative aspect - has been fulfilled. Finally, the research led to the following conclusions, all of them mathematically proven.

Two types of the building elements' defects take a major part in a rapid deterioration of an apartment house:

- calculated as a result of comparative analysis the defects caused by water penetration and humidity migration (gr. II); the rule is significant for the poorly maintained objects;

- determined as a result of fuzzy sets theory the mechanical defects of the structure and the surface of the elements (gr. I), which result in considerable frequency and cumulating effect and lead to permanent increase in the apartment houses elements' deterioration; the regularity is characteristic for well and average maintained objects.

Research of reason - effect relations "defect - technical wear" gives possibility to determine quantitatively an influence of apartment houses' maintenance on deterioration of their elements:

- practical application of simple operation in the fuzzy sets theory makes easier to connect the influence of elementary defects, occurring with certain frequency (probability) with their interrelation (correlation) on the apartment houses elements' observed technical wear;

- the proposed fuzzy model gives the possibility of identification this elementary defect which is responsible for the extreme degree „S" of the building element's;

- the degree of the building element's technical wear grows with declining of its maintenance conditions (though, not proportionally to the conditions of maintenance and not in the same way for different types of elements); in most cases (especially for the poorly maintained objects) this degree varies from the observed values of the technical wear calculated in probabilistic analysis;

- the elementary defect, which is responsible for the degree of the building element's, originates more often from the group of the defects of their structure and their surface than it took place in conventional preliminary analysis.

It is possible to calculate fuzzy relations $\mathrm{R} \subseteq \mathrm{Z} \times \mathrm{U}$ as quantitative values:

- exactly $30 \%$ out of 300 defects and technical wear elements degrees relations pair are linked with each other, $1 / 3$ of them indicates significant alliances;

- the height of the tested fuzzy relations is getting to normal not only as one maximum in the relation matrix but appears in $3 \%$ of $U_{i j}$ and $Z_{j}$ relations 


\section{DISCUSSION}

The core of the research led to seeking such mathematical models, which enabled to transfer a qualitative description of defects into a quantitative one based on fuzzy sets theory (when it is not sure that considered events exist) presented since sixties by Zadeh and Yager [14, 15] and in the mathematical system analysis by Kacprzyk [6] since middle eighties.

While assessing building elements' technical wear - apart from applying the measurable (qualitative) criteria - the immeasurable (quantitative) criteria representing symptoms (pinpointed defects) of their deterioration have been taken into account. Only very few of these criteria can be classified at high level of probability. There are symptoms of extreme characters, described by extreme dichotomise divisions. It is, however, agreed that between e.g. a total pest attack to wooden elements and its lack the mid-states appear. Their value is often appreciate in verbal way, e.g. "substantially", considerably", "significantly", "partially", "hardly" and it is always met in a description of detected defects as a result of a building objects technical inspections.

Therefore, the research led towards looking at the problem from the angle, which gave right to describe naturally qualitative variables (so immeasurable) and determine existing relations between them in fuzzy sets categories developed after Zadeh and Yager mainly by Ibadov and Kulejewski [4, 5] and Plebankiewicz $[9,10,11]$ in Poland. Advantages of fuzzy theory made possible to describe the defects in quantitative and measurable aspect.

The research - the methodological assumption, the mathematical procedure and the conclusions should be treated as an exploratory work. Thus, it is an attempt of the recognition of the mechanism of the reasons and effects phenomena, which an engineer expert faces to while technically inspecting a building object. This assessment, however, is naturally gifted with an immeasurable aspect (partly subjective). Creating a new model of apartment houses' technical inspection, based on procedures and conclusions drawn from the work, will make possible to transfer the weight of technical assessment from the qualitative form into quantitative one. The intention of the author is to direct the further work, connected with widely considered diagnoses of different kinds of buildings, towards the direction described above. 


\section{REFERENCES}

[1] H. M. Al-Humaidi, T. F. Hadipriono, "Fuzzy logic approach to model delays in construction projects using rotational fuzzy fault tree models", Civil Engineering and Environmental Systems 2010, pp. 329-351.

[2] M. Ammar, T. Zayed, O. Moselhi, "Fuzzy-based life-cycle cost model for decision making under subjectivity", Journal of Construction Engineering and Management, vol. 139(5), 2012, pp. 556-563.

[3] K. Y. Chan, C. K. Kwong, T. S. Dillon, K. Y. Fung, "An intelligent fuzzy regression approach for affective product design that captures nonlinearity and fuzziness", Journal of Engineering 2011, pp. 523-542

[4] N. Ibadov, "Fuzzy Estimation of Activities Duration in Construction Projects", Archives of Civil Engineering, vol LXI, 2015, pp. 23-34.

[5] N. Ibadov, J. Kulejewski, "Construction projects planning using network model with the fuzzy decision node", International Journal of Environmental Science and Technology, 2019, pp. 1-8,

[6] J. Kacprzyk, "Fuzzy sets in the system analysis", PWN, Warsaw, 1986.

[7] Multi-Author Work. "Assessment of Wrocław downtown apartment houses' technical conditions. Reports series "U" of Building Engineering Institute at Wrocław University of Technology Wrocław, 1984-96.

[8] F. Nasirzadeh, A. Afshar, M. Khanzadi, S. Howick, "Integrating system dynamics and fuzzy logic modelling for construction risk management”, Construction Management and Economics, 2008, pp. 1197-1212.

[9] E. Plebankiewicz, P. Karcińska, „Creating a Construction Schedule Specyfing Fuzzy Norms and the Number of Workers", Archives of Civil Engineering, vol LXII, 2016, pp. 149-166.

[10] E. Plebankiewicz, K. Zima, D. Wieczorek, „Life cycle cost modelling of buildings with consideration of the risk”, Archives of Civil Engineering, vol LXII, 2016, pp. 149-166.

[11] E. Plebankiewicz, K. Zima, D. Wieczorek, „Quantification of the risk addition in life cycle cost of a building object”, Technical Transactions, vol. 5/2017, pp. 35-45.

[12] E. Sanchez, "Eigen fuzzy sets and fuzzy relations", Memo, UCB/ERL/20, Berkeley, 1977.

[13] T. Trojanowski, "Buildings technical assessment". Kalendarz Przeglądu Budowlanego pod red. inż. I. Lufta. Wydawnictwo SZPB, tom II, Warszawa, 1938, pp.1719-1745.

[14] R. R. Yager, “On the fuzzy cardinality of a fuzzy set”, International Journal of General Systems 2007, pp. 191-206.

[15] L. Zadeh, "Fuzzy sets and systems", International Journal of General Systems, 1990, pp. 129-138.

\section{LIST OF FIGURES AND TABLES:}

Tab. 1. Result of fuzzy sets research of reason - effect relations "defect - technical wear" for 10 chosen apartment houses elements

Tab. 1. Wyniki rozmytych badań zależności przyczynowo - skutkowych "uszkodzenie - zużycie techniczne" dla 10 wybranych elementów budynków mieszkalnych

Tab. 2. Matrix of fuzzy relation $\mathrm{R}=\mathrm{Z} \times \mathrm{U}$ for 10 most critical building's elements and 30 detected defects

Tab. 2. Macierz relacji rozmytej $\mathrm{R}=\mathrm{Z}$ x U dla 10 najważniejszych elementów budynku i ich 30 zaobserowanych uszkodzeń 


\title{
OCENA TECHNICZNA STARYCH BUDYNKÓW PODEJŚCIEM ROZMYTYM
}

\author{
Slowa kluczowe: budynki, zużycie techniczne, uszkodzenie, zbiory rozmyte
}

\section{STRESZCZENIE}

Prawidłowa, tzn. systematycznie i rzetelnie przeprowadzana, ocena stanu technicznego starych budynków mieszkalnych stanowi podstawę do szeroko rozumianej organizacji ich obsługi technicznej, a w szczególności do organizacji prowadzenia remontów o ustalonym rodzaju, wielkości i zakresie. Ocena ta, poparta rozpoznaniem wpływu warunków utrzymania budynków mieszkalnych, jest ponadto podstawowym źródłem informacji w racjonalnym zarządzaniu zasobami mieszkaniowymi. Celem badań było rozpoznanie wpływu przebiegu procesów, utożsamianych z szeroko pojętym utrzymaniem starych budynków mieszkalnych o konstrukcji tradycyjnej, na wielkość i intensywność zużycia ich elementów. Cel pracy osiągnięto na drodze analizy objawów procesu technicznego zużycia - poznania mechanizmu zjawiska powstawania uszkodzeń oraz identyfikacji wielkości i intensywności uszkodzeń elementów badanych budynków. Etapem poprzedzającym zasadniczy zakres pracy było przeprowadzenie jakościowej analizy uszkodzeń elementów badanych budynków mieszkalnych. Charakterystyka techniczna i typologiczne uporządkowanie tych uszkodzeń, rozumianych jako wyraz jakości utrzymania budynków mieszkalnych, umożliwiły rozpoznanie warunków eksploatacji rozważanych obiektów. Konsekwencją usystematyzowania najistotniejszych procesów wpływających na utratę właściwości użytkowych budynków mieszkalnych było utworzenie własnego modelu jakościowego i jego transformacja na model ilościowy. Ten, z kolei, umożliwił przeprowadzenie wielokryterialnej ilościowej analizy zjawisk przyczynowo - skutkowych „uszkodzenie - zużycie techniczne” najważniejszych elementów śródmiejskich budynków mieszalnych w zbiorach w zbiorach rozmytych. W fazie rozmytej analizowano stany zaobserwowane zjawisk przyczynowo - skutkowych w warunkach rozmytości, czyli niepewności co do samego faktu ich występowania.

\section{PRÓBA BADAWCZA I IDENTYFIKACJA PROBLEMU}

Praca zawiera prace syntetyczne i analityczne oraz rozwiązania modelowe dotyczące problemów technicznego utrzymania i zużycia budynków mieszkalnych o konstrukcji tradycyjnej. Związki przyczynowo - skutkowe pomiędzy występowaniem uszkodzeń elementów kamienic czynszowych, traktowanych jako wyraz warunków ich utrzymania, a wielkością procesu technicznego zużycia tych elementów określono na reprezentatywnej, dobranej w sposób celowy, próbie 102 budynków mieszkalnych wzniesionych w drugiej połowie XIX i na początku XX wieku we wrocławskiej dzielnicy „Śródmieście;

Analiza studialna procesów eksploatacji obiektów mieszkalnych i wykonane w niej przekształcenia podstawowych zależności teorii niezawodności wskazuje, że dla okresu użytkowania obiektu, w którym czas poprawnej pracy do uszkodzenia ma rozkład wykładniczy (jest to w zasadzie okres eksploatacji odpowiadający długości czasu użytkowania rozważanych budynków mieszkalnych), średni pozostały czas bezawaryjnej pracy jest w każdym momencie niezmienny. Teoretycznie więc obiekty mieszkalne po upływie pewnego czasu bezawaryjnej pracy spełniają swoje funkcje tak jak nowe. Wiek elementów starego budynku mieszkalnego ma wtedy drugorzędne znaczenie w procesie intensywności utraty jego wartości użytkowych. Jeżeli przyjąć, że miarą dopasowania testowanych w metodzie regresji nieliniowej modeli matematycznych, jako funkcji zużycia technicznego elementów budynków w czasie, jest współczynnik determinacji, to nie więcej niż 30\% zniszczenia elementów jest wyjaśniona upływem czasu. Nie wiek zatem jest czynnikiem determinującym przebieg technicznego zużycia elementów analizowanych budynków.

O wielkości technicznego zużycia elementów starego budynku mieszkalnego decydują warunki jego utrzymania i użytkowania. Wyrazem stanu eksploatacji tego budynku, jako procesu odgrywającego największą rolę w jego przyśpieszonym niszczeniu, są postępujące uszkodzenia elementów spowodowane penetracją wody i przenikaniem wilgoci, istotne zwłaszcza dla budynków utrzymanych w sposób mierny

\section{ILOŚCIOWA OCENA STANU TECHNICZNEGO BUDYNKÓW PODEJŚCIEM ROZMYTYM}

W rachunku zbiorów rozmytych przeanalizowano stany zaobserwowane zjawisk przyczynowo - skutkowych uszkodzenie - zużycie techniczne w warunkach rozmytości, czyli subiektywności oceny technicznej i niepewności co do samego występowania uszkodzeń jako zdarzeń i relacji rozmytych.

Zastosowanie prostych operacji w rachunku zbiorów rozmytych umożliwia jednoczesne ujęcie wpływu uszkodzeń elementarnych, występujących z określoną częstością (prawdopodobieństwem), z miarą ich współzależności (korelacji) 
na zaobserwowane zużycie techniczne elementów budynku; w rezultacie uzyskuje się ponadto możliwość zidentyfikowania tego uszkodzenia elementarnego, które decyduje o stopniu zniszczenia elementu budynku.

Stopień uszkodzenia elementu wzrasta wraz z pogorszeniem się jego warunków utrzymania (choć nie proporcjonalnie do sposobów utrzymania i niejednakowo dla różnych rodzajów elementów); najczęściej różni się on od zaobserwowanych wartości stopnia technicznego zużycia ustalonego metodami konwencjonalnymi - zwłaszcza w miernych warunkach utrzymania budynku stopień uszkodzenia przekracza 70\% próg jego technicznego zużycia.

Elementarne uszkodzenie decydujące o stopniu zniszczenia elementu pochodzi znacznie częściej z grupy uszkodzeń mechanicznych struktury i faktury elementów niż miało to miejsce w konwencjonalnej analizie stanów zaobserwowanych; dopiero w miernych warunkach utrzymania budynku analiza zaobserwowanych stanów konwencjonalnych i rozmytych wykazuje duże podobieństwo - decydującym uszkodzeniem jest ponownie zniszczenie elementu spowodowane penetracją wody i przenikaniem wilgoci.

Prawdopodobieństwo warunkowe zużycia technicznego elementu względem jego uszkodzenia wzrasta wraz z pogorszeniem warunków utrzymania budynku (jest to wzrost wyjątkowo regularny, nawet w przypadku różnych elementów budynku); prawdopodobieństwo to charakteryzuje się niskim odchyleniem standardowym i wąskim zakresem rozpiętości wyników różnych elementów w obrębie każdego z rozważanych warunków utrzymania budynku zadowalających $(0,2622-0,3846)$, średnich $(0,3510-0,4613)$ i miernych $(0,4995-0,6466)$.

Dla każdego wybranych elementów budynków istnieją maksymalne i minimalne rozmyte równania relacyjne, a ich rozwiązania są podane $\mathrm{w}$ postaci czytelnych macierzy relacyjnych $(3 \times 3)$ określających dziedzinę i zakres maksymalnych i minimalnych relacji rozmytych, wysokość relacji rozmytych (która w przypadku maksymalnych rozwiązań w pracy wynosi 1 dla wszystkich analizowanych elementów, a w przypadku rozwiązań minimalnych - od 0,44 do 0,68 ) oraz różnice i miejsce ich występowania pomiędzy zależnościami maksymalnymi i minimalnymi; jeśli tych różnic nie ma rozwiązanie wskazuje dokładną wartość relacji rozmytej, występującą w różnych złożeniach, charakterystycznych dla różnych elementów budynku, przy czym najczęściej jest to złożenie środkowe, w którym relacje rozmyte przybierają wartości od 0,41 do 0,50 i dodatkowo 2-4 złożenia w innych miejscach.

\section{PODSUMOWANIE}

Wyniki pracy, opartej na badaniach jednorodnej, spójnej grupy śródmiejskich kamienic czynszowych, mają charakter indywidualny. Przeniesienie rezultatów oceny technicznej na inną populację budynków mieszkalnych o konstrukcji tradycyjnej powinno się cechować dużą ostrożnością i koniecznością wykonania badań sondażowych. Niewątpliwie takie badania powinny być poprzedzone starannym, celowym doborem typologicznej próby reprezentatywnej dla populacji generalnej. Próba taka może zawierać znacznie mniejszą liczbę obiektów, ale niezmiernie ważne jest, aby decydującym kryterium wyboru do pierwszoplanowej oceny technicznej były elementy (lub tylko ich części) istotne dla konstrukcji (ustroju nośnego) budynku. Taki podział ma szczególne znaczenie w przypadku badania elementów zespolonych i złożonych.

Omawiane dane ilościowe mogą stanowić podstawę do programowania wielkości i struktury specjalistycznych firm budowlanych zajmujących się konserwacją i remontami budynków mieszkalnych. Składają na informację techniczną niezbędną do zarządzania budynkami i projektowania organizacji tych działań obsługi technicznej obiektów mieszkalnych, które stanowią o jakości szeroko rozumianych warunków utrzymania zasobów mieszkaniowych. 